\title{
What Are the 21st-Century Skills for Pre-service Science and Mathematics Teachers: Discussion in the Context of Defined 21st-Century Skills, Self-skills and Education Curricula
}

\author{
Gülcan Mihladız Turhan (Corresponding author) \\ Department of Science Education, Faculty of Education \\ Burdur Mehmet Akif Ersoy University, Burdur, Turkey \\ Tel: 0090-248-213-4086_E-mail: gmihladiz@mehmetakif.edu.tr \\ Işı1 Açık Demirci \\ Department of Mathematics Education, Faculty of Education \\ Burdur Mehmet Akif Ersoy University, Burdur, Turkey \\ Tel: 0090-248-213-4000Ｅ-mail: idemirci@mehmetakif.edu.tr
}

Received: February 3, 2021 Accepted: March 1, $2021 \quad$ Published: March 15, 2021

doi:10.5296/jei.v7i1.18278ＵRL: https://doi.org/10.5296/jei.v7i1.18278

\begin{abstract}
The study aimed to determine the characteristics of pre-service teachers' 21 st-century skill concepts and their compatibility with the contemporary 21 st-century skill lists, 21 st-century self-skills and to compare and discuss, in terms of curricula and their fields. 71 pre-service science and 59 pre-service mathematics teachers were participated this phenomenological study. The statements by the participants were transformed into codes. These codes were categorized based on the framework for the 21 st century skills. 21 st-century skills codes with contemporary concepts relating to subcategories like "cognitive skills", "process skills", "communication and collaboration skills", "initiative and self-direction skills", "career skills", and "technology knowledge/usage/production skills" indicate that teacher candidates are knowledgeable about 21 st-century skills. Also the study found out that the greatest effects on the 21st-century skills of pre-service science and mathematics teachers are the curricula and the education they are taught. In this context, this research was based on the belief that
\end{abstract}


determining the influence of pre-service teachers' out-of-school and in-school trainings, their curricula, branches, etc. on their 21 st-century skills will be guiding in terms of organizing curricula and environments of education.

Keywords: Pre-service science teacher, Pre-service mathematics teacher, 21st century skills, 21 st-century self-skills, Education curriculums

\section{Introduction}

Today, a growing environment of breakthroughs in areas such as defense industry, space technologies, technological and scientific development, quality production, inventions, coping with environmental problems, and decreasing resources in the context of the development policies of countries has raised these countries' interest in science, engineering and innovative technologies, urging them to focus on the fields of education and investment (Akgündüz et al., 2015; Turkey's Ministry of National Education [MEB], 2017; Chalkiadaki, 2018; Mullis, 2019). Along with the digitalization process, changes have also occurred in labour markets and individual competencies. In this context, skills that play a key role in teaching students deep understanding of knowledge and facilitating the transfer of knowledge to new environments gain more importance (Bialik \& Fadel, 2015). The report (Organization for Economic Cooperation and Development [OECD], 2017) which suggests that literacy, problem-solving skills, information and communications skills, management and communication, STEM (Science, Technology, Engineering and Mathematics) skills, and self-organization and learning readiness skills are on higher levels in those industries where digitalization is higher demonstrates the current understanding of skill. Explaining that especially those teachers who teach STEM lessons benefit from the use of technology in the educational environment more than other teachers, Siddiq, Scherer, and Tondeur (2016) state that, as a reflection of this, the skills and the education conception of the new century are in a mutual balance. This suggests that the 21st-century conception of education is based on equipping individuals with the skills required by this century (Bozkurt Altan, 2017). Due to the conditions and complex problems of the 21 st century, therefore, individuals living in the information and technology society of this age are expected to have high-level skills such as critical thinking, decision-making, communications, creative thinking and problem solving rather than just content-oriented teaching and talent development processes (Turkey Competences Framework [TYC], 2015; Kozikoğlu \& Altunova, 2018; Astuti et al., 2019).

In order for the expectations to be met, skills and characteristics must first be defined. Gardner and Hatch (1989) emphasize that recognizing children's mental strengths and areas of activity is perhaps the smartest thing to do. For curriculum redesign, Bialik and Fadel (2015) showed the scope and complex structure of the 21 st century, emphasizing curricular elements with a model in which " 21 st-century education" is situated at the intersection of knowledge, skills and character in a cluster formed by metacognition. In the context of understanding, teaching, questioning and improving 21 st-century skills, many studies have been conducted on the use and positive effects of contemporary approaches such as project-based learning (Bell, 2010), engineering design processes (Sadusky, 2012; Wan Husin et al., 2016; Şen, Ay, \& Kiray, 2018;), constructivist approach/5-E instructional model 
(Kivunja, 2015) and project-oriented problem-based learning (Wan Husin et al., 2016). To this end, many countries aim to renew, update and improve their curricula. Various curricula and educational reports prepared (National Academy of Sciences, 2007; Silva, 2008; American Association of School Librarians [AASL], 2009; National Science Board [NSB], 2010; National Research Council [NRC], 2012; MEB, 2018a, 2018b) offer visions regarding the scope and quality of science, engineering and technology education necessary for students and teachers to adapt to the 21 st century and to increase their literacy level in many areas.

In line with the education and production visions of countries, skill frameworks related to the needed 21 st-century learner and teacher skills are offered and steadily updated in the form of comprehensive and ever-expanding skills lists by various national education associations and institutions that aim to define and explain individual competencies and industrial organizations that care about business potential (Lemke, 2002; AASL, 2009; Binkley et al., 2010; NRC, 2012; TYC, 2015; MEB, 2017; OECD, 2018; Partnership for 21st-Century Skills [P21], 2019). These associations and organizations have examined 21st-century skills under various groups within their own dynamics and discussed what they bring to the individual. It can be said, however, that, in general, the ultimate goal is to raise ethical and self-organizing individuals who are open to change and can keep up with contemporary life, the 21 st century or the digital world, and produce. Examples of these skills include problem solving, social skills, creative thinking, critical thinking, digital literacy, entrepreneurship, life and career skills, and self-regulation skills (Table 1). The frameworks for 21st-century skills presented by organizations and institutions (P21, OECD, NRC, ATC21S, NCREL's enGauge) that are primarily considered in the present research, the categories they take as a basis and the basic 21 st-century skills related to these categories, are presented in an arrangement in Table 1 in order to provide a holistic perspective.

Table 1. $21^{\text {st }}$-Century Skills Frameworks offered by various educational organizations

\begin{tabular}{|c|c|c|}
\hline $\begin{array}{l}21^{\text {st }} \text { Century } \\
\text { Skills Frameworks }\end{array}$ & Skills Categories & $21^{\text {st }}$ Century Skills \\
\hline \multirow{4}{*}{$\begin{array}{l}\text { P21 (Partnership for } \\
\text { 21st Century } \\
\text { Learning) 21st } \\
\text { Century Student } \\
\text { Outcomes (2019) }\end{array}$} & 21st Century Themes & $\begin{array}{l}\text { - } \text { Global awareness } \\
\text { - Financial, economic, business and entrepreneurial } \\
\text { literacy } \\
\text { - } \text { Civic literacy } \\
\text { - Health literacy } \\
\text { - Environmental literacy }\end{array}$ \\
\hline & Learning and Innovation Skills & $\begin{array}{l}\text { - } \text { Creativity and innovation } \\
\text { - } \quad \text { Critical thinking and problem solving } \\
\text { - } \quad \text { Communication and collaboration }\end{array}$ \\
\hline & $\begin{array}{l}\text { Information, Media, and } \\
\text { Technology Skills }\end{array}$ & $\begin{array}{ll}\text { - } & \text { Information literacy } \\
\text { - } & \text { Media literacy } \\
\text { - } & \text { ICT literacy }\end{array}$ \\
\hline & Life and Career Skills & $\begin{array}{ll}\text { - } & \text { Flexibility and adaptability } \\
\text { - } & \text { Initiative and self-direction } \\
\text { - } & \text { Social and cross-cultural skills } \\
\text { - } & \text { Productivity and accountability } \\
\text { - } & \text { Leadership and responsibility }\end{array}$ \\
\hline
\end{tabular}




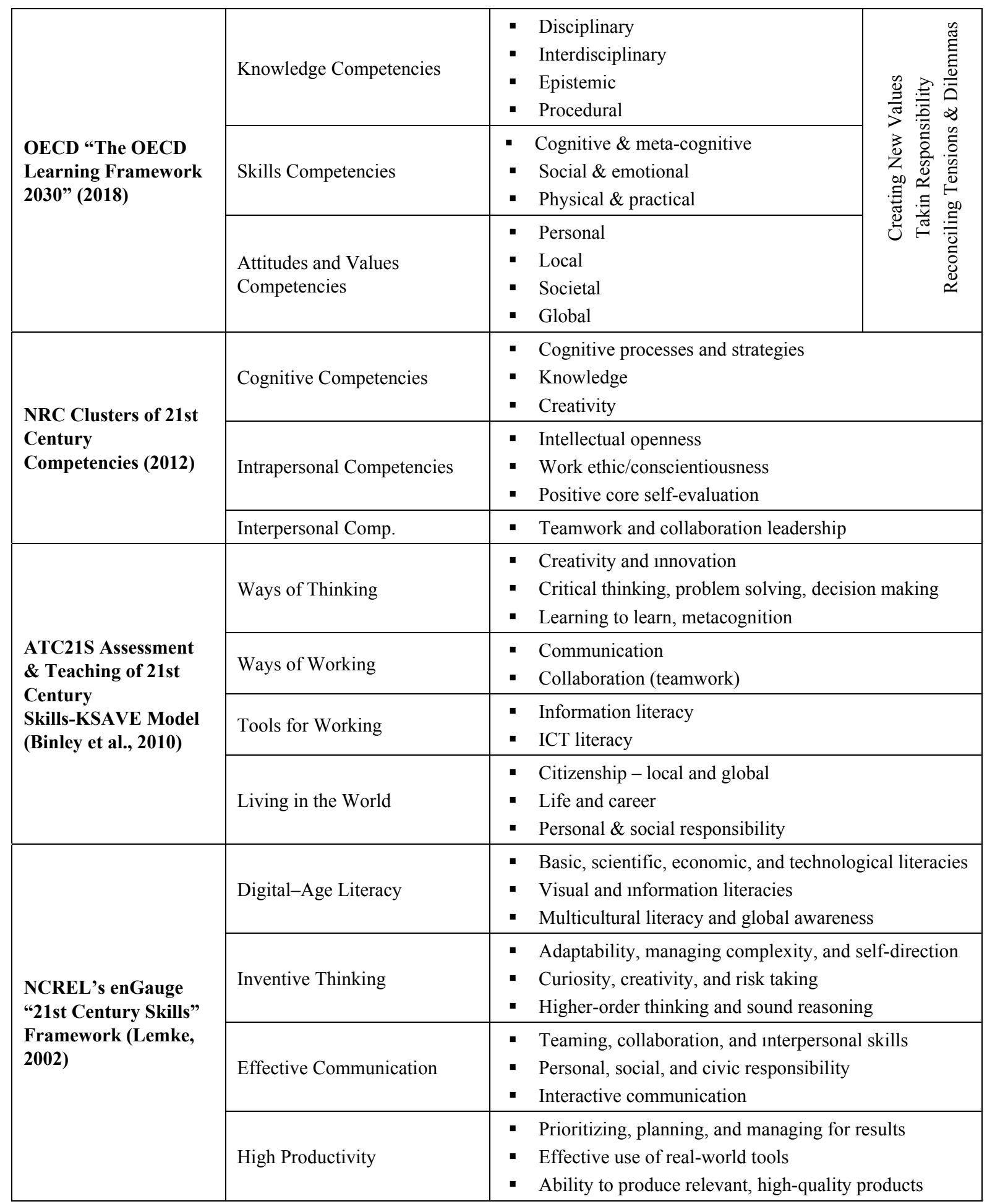

In order to raise individuals with all these skills, it is necessary to bring together the elements of an effective teacher education model for meeting the needs of the 21 st century (Hacioglu, 1990), provide teacher training at an international level, and ensure that teachers become people who are sensitive to all the problems around them, who produce solutions, and have a stance (Tutkun \& Aksoyalp, 2010). Considering the importance of well-trained teachers in teaching thinking skills (Korkmaz, 2009), the positive effects of educational practices can be 
seen when these teachers present important ideas in different ways and give students the opportunity to show what they have learned (Mihladiz, 2017). Most pre-service teachers need professional development in order to structure their teaching in terms of 21 st-century skills (Bedir, 2019). In this regard, it is necessary to train pre-service teachers for developing 21st-century learner skills (Göksün \& Kurt, 2017) and provide an educational environment where they can gain these skills (Jacobson-Lundeberg, 2016).

For the aforementioned reasons, there is a need for studies to determine the situation of teachers and pre-service teachers, who are teachers of the future, in terms of forming reasonable perceptions about 21st-century learning (Sang et al., 2018) and the extent to which they possess 21st-century skills (Kozikoğlu \& Altunova, 2018). In this sense, the present study discussed issues such as the perspectives of teachers in different branches on 21 st-century literacy (Lyons \& Wells, 2015), development of 21st-century social skills (Farisi, 2016), the concept of skill (Karademir, Sarıkahya, \& Altunsoy, 2017) and 21st-century learning competencies (Sang et al., 2018). As for pre-service teachers, some examples of studies are mentioned regarding their views on 21st-century learner characteristics as expressed through "student of the future" tweets (Günüç, Odabaş1, \& Kuzu, 2013), a comparison of 21st-century learner and teacher skills (Göksün \& Kurt, 2017), their evaluations about acquisition of 21st-century skills (Aslan, 2015), modelling and development of 21st-century skills (Urbani et al., 2017), teaching of 21st-century competencies (Trinidad et al., 2013), basic dimensions of 21st-century competencies (Almerich et al., 2018), and their opinions about the use of 21st-century learner and teacher skills (Tican \& Deniz, 2019).

The study is important in terms of contributing a different perspective to the literature, identifying various situations that lead pre-service teachers to differentiate in their 21 st-century skills concepts, identifying the educational processes that are effective in their acquisition of these concepts, and revealing the self-skill concepts related to 21 st-century skills. It aimed to determine the characteristics of 21 st-century skill concepts of pre-service teachers and their compatibility with the contemporary 21 st-century skill lists, and to compare and discuss, in terms of curricula, the concepts of 21 st-century skills and 21 st-century self-skills of pre-service teachers attending the departments of science and mathematics teaching, which are among the areas of STEM education that focuses on 21 st-century skills. This research was based on the belief that determining the influence of pre-service teachers' out-of-school and in-school trainings, their curricula, branches, etc. on their 21 st-century skills will be guiding in terms of organizing curricula and environments of education. In this respect, the main purpose of the study was to determine what 21 st century skills an individual should have for pre-service science and mathematics teachers. With this purpose, answers to the research questions below were sought;

- What are the concepts of pre-service science and mathematics teachers about 21 st-century skills?

- What is the level of similarity between the skills included in national and international 21 st-century skill frameworks and the 21 st-century skills reported by pre-service science and 
mathematics teachers?

- What are the views of pre-service science and mathematics teachers about their 21 st-century self-skills?

- What are the differences and similarities between the 21 st-century skill concepts that pre-service science and mathematics teachers have on the basis of their education department?

- What are the educational practices such as lessons, courses, projects etc. that were effective in science and mathematics teacher candidates' knowing and learning the 21 st-century skills they specified?

- What is the effect of curricula on 21 st-century skill concepts of pre-service science and mathematics teachers?

\section{Method}

\subsection{Research Design}

This study investigated pre-service science and mathematics teachers' understanding of the concept of " 21 st-century skills" and their ideas about which of these skills they have. In this sense, this is a phenomenological research. Descriptive or interpretive phenomenological studies are based on personal experience and require an explanation or interpretation of the meanings of phenomena experienced by research participants. Therefore, purposive sampling is preferred in phenomenological studies (Padilla-Diaz, 2015). As regards pre-service teachers from the fields of Science and Mathematics, which are among the STEM education fields that aim to teach 21 st-century skills, the present study tried to reveal their conceptual schemes of the phenomenon of 21 st-century skills.

\subsection{Participants}

The participants of the study consisted of 3rd-grade students attending the Science Education Department or Mathematics Education Department of a state university. A total of 130 pre-service teachers, including 71 science and 59 mathematics pre-service teachers, participated in the study

\subsection{Data Collection Tool and Process}

A personal information form and a semi-structured interview form were used as the data collection tool in the study. The personal information form included questions about the demographic characteristics of candidates such as name-surname, gender, department, grade information, their participation in any training, lesson, course or project that will enable them to obtain information about 21st-century skills, as well as further information about such trainings. The semi-structured interview form presented below the personal information form was divided into two columns with the questions of item 1 on the left and those of item 2 on the right column. In the 1 st item, pre-service teachers were asked to state " 21 st-century skills that an individual can have", and, in the 2nd item, to list "the ones they think they already possess". 


\subsection{Data Analysis}

The statements of pre-service science and mathematics teachers regarding 21 st-century skills were evaluated by researchers in accordance with qualitative research methodology and transformed into common codes. The concepts used in coding can come from a) the researcher themselves, b) the literature they have read, or c) the data itself (Y1ldirım \& Şimşek, 2008). In this sense, data sets containing both the literature, that is, the 21 st-century skill lists, and the interview statements of candidates, were used as the code sources of the study. The fact that candidates wrote their answers as a list and that these answers were in high agreement with the literature increased the validity and reliability of the coding. In addition, the entire data set was reviewed at the same time by two researchers, and the codes were structured with a consensus by discussing even the slightest differences in the answers. Codes are essential elements that explain the essence of the subject investigated; when they are clustered based on similarity and a certain order, that is, when they form a pattern, this effectively makes it easier to develop categories and thus analyse the connections between them (Saldana, 2019). In order to establish meaningful relationships and reveal patterns between pre-service teachers' concepts related to 21 st-century skills, the obtained skill codes were gathered under categories created by making use of the subheadings in the 21 st-century skill frameworks of national and international organizations such as OECD, EnGauge, MEB, P21, AASL, and ATC21S. Carrying out "Descriptive Analysis" on the basis of each research problem, percentage and frequency values were given based on the data obtained. Moreover, the 21 st-century skill concepts of candidates were compared with the skill lists and it was tried to analyse their experiences and self-efficacy related to these skills on the basis of their branches, the trainings they received and their curricula.

\section{Results}

This study tried to reveal what 21 st-century skills are for pre-service science and mathematics teachers and which of these skills they think they have. In this context, research findings were discussed in two sections including "21st-century skills" (Tables 2 and 3), which refers to the skills that an individual can have, and "21st-century Self-skills" (Tables 4 and 5), which refers to pre-service teachers' own 21 st-century skills. In each section, the skill codes of pre-service science and mathematics teachers were compared on the basis of 21 st-century skill categories created from research codes in consideration of the skill lists classified according to various scientific criteria by national and international education organizations (OECD, EnGauge, MEB, P21, AASL, and ATC21S).

The codes obtained from the answers of candidates were basically categorized as "Learning and Innovation Skills", "Life and Career Skills" and "Technological Skills". Table 1 shows the frequencies of the codes of science and mathematics teacher candidates regarding 21 st-century skills. Also, Table 2 presents the categories and sub-categories of the research, and codes relating to 21 st-century skills with high frequency. 
Table 2. Frequency distributions regarding 21st-Century Skills Codes of pre-service science and mathematics teachers

\begin{tabular}{|c|c|c|c|c|c|}
\hline $\begin{array}{l}\text { Skill } \\
\text { Categories }\end{array}$ & Subcategories & $\begin{array}{l}\text { Pre-service Science } \\
\text { Teacher Codes }\end{array}$ & f & $\begin{array}{l}\text { Pre-service Math } \\
\text { Teacher Codes }\end{array}$ & f \\
\hline \multirow{18}{*}{ 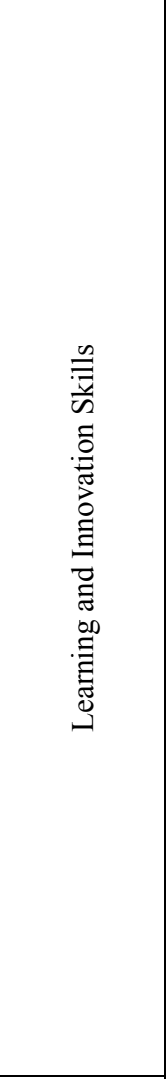 } & \multirow{7}{*}{ Cognitive Skills } & Creativity-Creative Thinking & 43 & Creativity-Creative Thinking & 17 \\
\hline & & Innovation Skills & 35 & Imagination & 16 \\
\hline & & Analytical Thinking & 27 & Problem-Solving & 15 \\
\hline & & Logical Thinking & 10 & Innovation Skills & 14 \\
\hline & & Comprehension-explanation & 10 & Openness to Learning & 9 \\
\hline & & Three-dimensional thinking & 9 & Critical Thinking & 9 \\
\hline & & Other skills ( 22 codes) & 79 & Other skills ( 6 codes $)$ & 25 \\
\hline & \multirow{6}{*}{ Process Skills } & Scientific Process Skills & 41 & $\begin{array}{l}\text { Conducting Scientific } \\
\text { Research }\end{array}$ & 6 \\
\hline & & Psychomotor Skills & 30 & Intelligence Games & 5 \\
\hline & & $\begin{array}{l}\text { Conducting Scientific } \\
\text { Research }\end{array}$ & 14 & Using Materials & 2 \\
\hline & & Experiment/Laboratory Skill & 12 & Gaining Experience & 1 \\
\hline & & Design Skill & 12 & - & - \\
\hline & & Other skills ( 6 codes $)$ & 29 & - & - \\
\hline & \multirow{5}{*}{$\begin{array}{l}\text { Communication and } \\
\text { Collaboration Skills }\end{array}$} & Communications Skill & 19 & Communication Skill & 27 \\
\hline & & Collaboration/Teamwork & 18 & Sociality & 10 \\
\hline & & Native/Foreign Language & 11 & Native/Foreign Language & 10 \\
\hline & & Sociality & 5 & Adaptation Skill & 8 \\
\hline & & Adaptation Skill & 1 & Collaboration/Teamwork & 3 \\
\hline \multirow{14}{*}{ 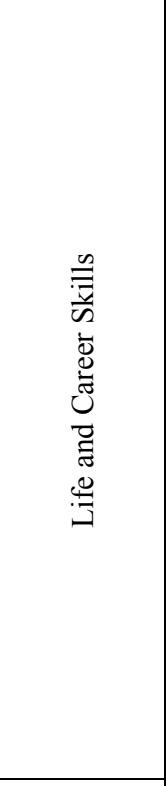 } & \multirow{5}{*}{$\begin{array}{l}\text { Initiative and } \\
\text { Self-Direction Skills }\end{array}$} & Entrepreneurship & 13 & Entrepreneurship & 19 \\
\hline & & Life Skills & 10 & Social and Cross-Cultural & 10 \\
\hline & & Financial Skill & 6 & Leadership & 9 \\
\hline & & Accountability & 5 & Accountability & 8 \\
\hline & & Other skills (4 codes) & 9 & Other skills (7 codes) & 33 \\
\hline & \multirow{4}{*}{ Attitude and Values Skills } & Curiosity & 8 & Curiosity & 11 \\
\hline & & Scientific Attitude & 5 & Ethical Attitude & 11 \\
\hline & & Versatility & 1 & Being Sensitive & 9 \\
\hline & & Ethical Attitude & 3 & Other skills (6 codes) & 13 \\
\hline & \multirow{5}{*}{ Career-Related Skills } & Engineering Design & 47 & Professional Field Knowledge & 9 \\
\hline & & Scientific Literacy & 16 & Artistic-Visual Skill & 3 \\
\hline & & Artistic-Visual Skill & 13 & STEM & 3 \\
\hline & & STEM & 8 & - & - \\
\hline & & Other skills ( 3 codes) & 11 & - & - \\
\hline \multirow{5}{*}{ 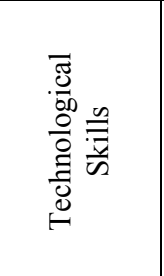 } & \multirow{5}{*}{$\begin{array}{l}\text { Technology Knowledge/Usage/ } \\
\text { Production Skills }\end{array}$} & Using Technology & 16 & Using Technology & 47 \\
\hline & & Software-Coding & 13 & Technological knowledge & 18 \\
\hline & & Robotics & 5 & Digital Media Literacy & 16 \\
\hline & & Digital Media Literacy & 3 & Software-Coding & 13 \\
\hline & & Other skills ( 3 codes) & 5 & Other skills ( 2 codes $)$ & 4 \\
\hline
\end{tabular}


Table 2 shows that science and mathematics teacher candidates have a general view about 21 st-century skills. Considering the variety and number of skills, it is possible to say that pre-service teachers in both branches have sufficient knowledge on this subject. Furthermore, pre-service science and mathematics teachers generally master similar individual skill codes, even if at different frequencies.

It attracts attention in Table 2 that teacher candidates also had a command of skills which are common in many frameworks, such as creativity-creative thinking, innovation skills, scientific process skills, design skills, communication skills, collaboration, entrepreneurship, social and cross-cultural skills, ethical skills, engineering design, technological knowledge, using technology, coding-software, robotics, etc., with high frequency. Table 3 provides frequency and percentage values for 21 st-century skill categories that combine " 21 st-century skills" codes under specific headings, on which pre-service teachers expressed more common views based on their branches.

Table 3. Frequency and percentage distributions of pre-service science and mathematics teachers regarding 21 st-Century Skills Subcategories

\begin{tabular}{|l|l|l|l|l|l|}
\hline \multirow{2}{*}{$21^{\text {st }}$-Century Skills Categories } & \multirow{2}{*}{ Subcategories } & \multicolumn{2}{|c|}{$\begin{array}{c}\text { Science Code } \\
\text { Distributions }\end{array}$} & \multicolumn{2}{|c|}{$\begin{array}{c}\text { Mathematics Code } \\
\text { Distributions }\end{array}$} \\
\cline { 3 - 6 } & & $\mathbf{f}$ & $\mathbf{\%}$ & $\mathbf{f}$ & $\mathbf{\%}$ \\
\hline \multirow{4}{*}{ Learning and Innovation Skills } & Cognitive Skills & 213 & 35.382 & 105 & 25.424 \\
\cline { 2 - 6 } & Process Skills & 138 & 22.924 & 14 & 3.390 \\
\cline { 2 - 6 } & Communication and Collaboration Skills & 54 & 8.970 & 58 & 14.044 \\
\hline \multirow{3}{*}{ Life and Career Skills } & Initiative and Self-Direction Skills & 43 & 7.143 & 79 & 19.128 \\
\cline { 2 - 6 } & Attitude and Values Skills & 17 & 2.824 & 44 & 10.654 \\
\cline { 2 - 6 } & Career Skills & 95 & 15.781 & 15 & 3.632 \\
\hline \multirow{2}{*}{ Technological Skills } & $\begin{array}{l}\text { Technology Knowledge/Use/ } \\
\text { Production Skills }\end{array}$ & 42 & 6.977 & 98 & 23.729 \\
\hline & Total & 602 & 100 & 413 & 100 \\
\hline
\end{tabular}

In Table 3, the code percentages of the skills expressed by teacher candidates show that the highest participation in both branches belongs to the "learning and innovation skills" category. Pre-service science teachers have more common and high frequency codes in "cognitive skills", "process skills", "career-related skills", and their skill ratios in these sub-categories are higher than pre-service mathematics teachers. Pre-service mathematics teachers, on the other hand, stated more common views on "cognitive skills", "technology knowledge/usage/production producing skills", "initiative and self-direction skills", "communication and collaboration skills", and "attitude and value skills". In four of these sub-categories, they had a higher rate of skill codes than pre-service science teachers.

During the research process, the views of candidates were taken about not only 21 st-century skills but also the 21 st-century self-skills they had. In this context, Table 4 includes the 


\section{Macrothink}

percentage analysis of the number of skill statements directly made by pre-service teachers, which were obtained without coding regarding individual and self-skills.

Table 4. 21st-Century Self-skills Competency Views of pre-service science and mathematics teachers

\begin{tabular}{|l|l|l|l|l|}
\hline Pre-service Teachers & $\mathbf{N}$ & $\begin{array}{l}\mathbf{2 1}^{\text {st }} \text {-century skills } \\
\text { statements }\end{array}$ & $\begin{array}{l}\mathbf{2 1}^{\text {st }} \text {-century self-skills } \\
\text { statements }\end{array}$ & $\begin{array}{l}\text { Self-skill competency } \\
\text { percentage }\end{array}$ \\
\hline Science & 71 & 116 & 79 & $\% 68.10$ \\
\hline Mathematics & 59 & 94 & 62 & $\% 65.96$ \\
\hline
\end{tabular}

As seen in Table 4, 116 statements of 21 st-century skills were obtained from 71 science teacher candidates, while 94 statements of 21 st-century skills were obtained from 59 mathematics teacher candidates as raw data. The number of skills they think they have among these skills is 79 in science teaching and 62 in mathematics teaching. In this respect, candidates generally think that they do not have all the 21 st-century skills that they stated in general. The rates of the self-skill competency perceptions of pre-service science teachers $(68.10 \%)$ and mathematics $(65.96 \%)$ were close to each other.

In the study, the code list for 21st-century skills was used for self-skills in the same way, and the codes were classified under categories created again on the basis of 21 st-century skill frames. The frequency distributions of teacher candidates regarding 21st-century self-skill codes are presented in Table 5. 
Table 5. Frequency distributions regarding 21st-Century Self-Skill Codes of pre-service science and mathematics teachers

\begin{tabular}{|c|c|c|c|c|c|}
\hline $\begin{array}{l}\text { Skill } \\
\text { Categories }\end{array}$ & Subcategories & $\begin{array}{l}\text { Pre-service Science } \\
\text { Teacher Codes }\end{array}$ & $\mathbf{f}$ & $\begin{array}{l}\text { Pre-service Math } \\
\text { Teacher Codes }\end{array}$ & f \\
\hline \multirow{15}{*}{ 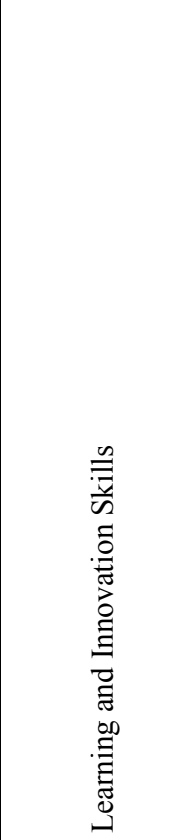 } & \multirow{6}{*}{ Cognitive Skills } & Creativity-Creative Thinking & 28 & Imagination & 10 \\
\hline & & Innovation Skills & 12 & Problem-Solving & 8 \\
\hline & & Analytical Thinking & 9 & Creativity-Creative Thinking & 6 \\
\hline & & Comprehension-explanation & 6 & Innovation Skills & 5 \\
\hline & & Decision making & 6 & Openness to Learning & 5 \\
\hline & & Other skills (17 codes) & 44 & Other skills ( 7 codes) & 18 \\
\hline & \multirow{5}{*}{ Process Skills } & Scientific Process Skills & 33 & Conducting Scientific Research & 5 \\
\hline & & Psychomotor Skills & 21 & Intelligence Games & 2 \\
\hline & & Experiment/Laboratory Skill & 12 & Using Materials & 2 \\
\hline & & Design Skill & 11 & Psychomotor Skills & 1 \\
\hline & & Other skills ( 5 codes) & 23 & - & - \\
\hline & \multirow{4}{*}{$\begin{array}{l}\text { Communication and } \\
\text { Collaboration Skills }\end{array}$} & Communications Skill & 16 & Communication Skill & 18 \\
\hline & & Collaboration/Teamwork & 13 & Adaptation Skill & 5 \\
\hline & & Native/Foreign Language & 4 & Collaboration/Teamwork & 3 \\
\hline & & Other skills ( 2 codes $)$ & 3 & Native/Foreign Language & 1 \\
\hline \multirow{12}{*}{ 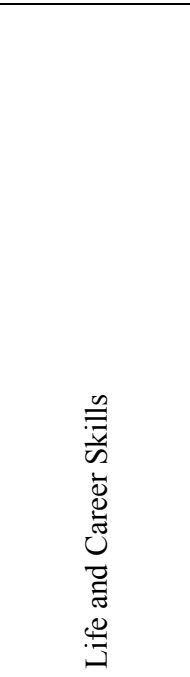 } & \multirow{4}{*}{$\begin{array}{l}\text { Initiative and } \\
\text { Self-Direction Skills }\end{array}$} & Entrepreneurship & 5 & Accountability & 7 \\
\hline & & Life Skills & 4 & Entrepreneurship & 6 \\
\hline & & Accountability & 3 & Self-confidence & 6 \\
\hline & & Other skills ( 3 codes) & 5 & Other skills ( 5 codes $)$ & 13 \\
\hline & \multirow{4}{*}{ Attitude and Values Skills } & Curiosity & 6 & Ethical Attitude & 10 \\
\hline & & Scientific Attitude & 1 & Curiosity & 9 \\
\hline & & Versatility & 1 & Being Sensitive & 3 \\
\hline & & - & - & Other skills (3 codes) & 6 \\
\hline & \multirow{4}{*}{ Career-Related Skills } & Engineering Design & 14 & Professional Field Knowledge & 3 \\
\hline & & Scientific Literacy & 7 & Artistic-Visual Skill & 1 \\
\hline & & Artistic-Visual Skill & 5 & - & - \\
\hline & & Other skills ( 2 codes) & 4 & - & - \\
\hline \multirow{3}{*}{$\begin{array}{l}\text { Technological } \\
\text { Skills }\end{array}$} & \multirow{3}{*}{$\begin{array}{l}\text { Technology } \\
\text { Knowledge/Usage/ } \\
\text { Production Skills }\end{array}$} & Using Technology & 10 & Using Technology & 30 \\
\hline & & Software-Coding & 3 & Software-Coding & 16 \\
\hline & & Other skills ( 3 codes) & 5 & Digital Media Literacy & 6 \\
\hline
\end{tabular}

As can be seen in Table 5, pre-service science and mathematics teachers think that they have many skills that are also included in the 21 st-century skill frames. As for the 21 st-century self-skills of candidates on a branch basis, it can be said that they specified similar skills, albeit at different frequencies.

A comparison of Table 2 and Table 5 for pre-service science teachers shows that, regarding 
the skills that they mostly agreed from among the 21 st-century skills that an individual can have, they also listed these among their own self-skills with low participation but in the same order. Among these skills, those with high frequencies included, again, creativity-creative thinking, innovation, scientific process skill, psychomotor skills, experiment/laboratory skill, design skill, communication skills, collaboration/teamwork, engineering design and technology usage skills. An examination of Table 2 and Table 5 for pre-service math teachers reveals that what they listed as 21 st-century skills they also specified as 21 st-century self-skills at a lower frequency and in a different order in some categories. Self-skill codes with more participation included imagination, problem solving, carrying out scientific research, communication skill, accountability, ethical attitude, technology usage, and software-coding. The self-skill codes of teacher candidates are given in Table 6 with their total frequencies on the basis of sub-categories.

Table 6. Frequency and percentage distributions of pre-service science and mathematics teachers regarding 21st-Century Self-Skills Subcategories

\begin{tabular}{|l|l|l|l|l|l|}
\hline \multirow{2}{*}{$\begin{array}{l}\text { 21st-century } \\
\text { self-skills Categories }\end{array}$} & Subcategories & \multicolumn{2}{|c|}{$\begin{array}{c}\text { Science Code } \\
\text { Distributions }\end{array}$} & \multicolumn{2}{|c|}{$\begin{array}{c}\text { Mathematics Code } \\
\text { Distributions }\end{array}$} \\
\cline { 2 - 6 } & & $\boldsymbol{f}$ & $\boldsymbol{\%}$ & $\boldsymbol{f}$ & $\%$ \\
\hline \multirow{4}{*}{$\begin{array}{l}\text { Learning and } \\
\text { Innovation Skills }\end{array}$} & Cognitive Skills & 105 & 33.440 & 52 & 25.366 \\
\cline { 2 - 7 } & Process Skills & 100 & 31.847 & 10 & 4.878 \\
\cline { 2 - 7 } & $\begin{array}{l}\text { Communication and } \\
\text { Collaboration Skills }\end{array}$ & 36 & 11.465 & 27 & 13.171 \\
\hline \multirow{3}{*}{ Life and Career Skills } & Initiative and Self-Direction Skills & 17 & 5.414 & 32 & 15.610 \\
\cline { 2 - 7 } & Attitude and Values Skills & 8 & 2.548 & 28 & 13.659 \\
\cline { 2 - 7 } & Career Skills & 30 & 9.554 & 4 & 1.951 \\
\hline \multirow{2}{*}{ Technological Skills } & $\begin{array}{l}\text { Technology Knowledge/Use/ } \\
\text { Production Skills }\end{array}$ & 18 & 5.733 & 52 & 25.366 \\
\hline & Total & 314 & 100 & 205 & 100 \\
\hline
\end{tabular}

In Table 6, it is noteworthy that pre-service science teachers have a consensus on 21 st-century self-skills, and the three highest frequency subcategories belong to the learning and innovation skills category. It was also ascertained that 21st-century self-skills of pre-service mathematics teachers displayed a wider distribution on the basis of sub-categories belonging to all three categories. The competency perceptions of teacher candidates regarding 21 st-century self-skills are differentiated on the basis of sub-categories.

While teacher candidates participating in the study listed their undergraduate courses in the section regarding resources and trainings that were effective in their learning and application of 21 st-century skills, 15 pre-service science teachers and 20 pre-service mathematics teachers also stated that they participated in courses and projects in different fields like a robotics-coding course, etc. It was learned from these candidates that these trainings they attended were courses that lasted a few months and some projects that covered a period of 
one or two weeks. The courses, undergraduate lessons, projects and trainings specified by teacher candidates are listed in Table 7 by frequency and percentage values.

Table 7. Frequency and percentage distributions regarding the resources and trainings that Enabled Teacher Candidates to Learn 21st-Century Skills

\begin{tabular}{|l|l|l|l|l|l|l|}
\hline Codes of Pre-service Science Teachers & $\mathbf{f}$ & $\mathbf{\%}$ & Codes of Pre-service Math Teachers & $\mathbf{f}$ & $\mathbf{\%}$ \\
\hline Nature of Science and History of Science Course & 33 & 46.48 & Project participation & 11 & 18.64 \\
\hline Special Teaching Methods Course & 15 & 21.13 & $\begin{array}{l}\text { Technological Programs and Their } \\
\text { Application }\end{array}$ & 71.86 \\
\hline $\begin{array}{l}\text { Science Teaching Practices and Curriculum } \\
\text { Development Courses }\end{array}$ & 10 & 14.08 & $\begin{array}{l}\text { Education Technologies and Material } \\
\text { Design Course }\end{array}$ & 7 & 11.86 \\
\hline $\begin{array}{l}\text { Instructional Technologies and Material Design } \\
\text { Course }\end{array}$ & 8 & 11.27 & $\begin{array}{l}\text { Geometry Education and Related } \\
\text { Computer Courses }\end{array}$ & 6 & 10.17 \\
\hline Constructivism and Training Practices Course & 8 & 11.27 & Robotic Coding Education/Course & 6 & 10.17 \\
\hline $\begin{array}{l}\text { Robotic Coding Education/Course } \\
\text { Science and Technology Curriculum and }\end{array}$ & 8 & 11.27 & $\begin{array}{l}\text { Special Education Principles and Methods } \\
\text { Pourse }\end{array}$ & 4 & 6.78 \\
\hline Scientific Research Methods Course & 7 & 9.86 & Community Service Practices Course & 3 & 5.08 \\
\hline STEM Seminar/distance education/conference & 6 & 8.45 & Education Principles and Methods Course & 3 & 5.08 \\
\hline Project participation & 5 & 7.04 & Mathematics and Life Course & 2 & 3.39 \\
\hline Others (6 resources) & 14 & 5.63 & Others (7 resources) & 11 & 3.39 \\
\hline
\end{tabular}

As is seen in Table 7, the examples given by a majority of 71 pre-service science teachers about resources of knowledge on 21st-century skills mostly included their undergraduate courses. The most specified undergraduate courses included "Nature of Science and History of Science Course" with a participation rate of 46.48\%, "Special Teaching Methods Course" with 21.13\%, "Science Teaching Practices and Curriculum Development Courses" with 14.08\%, and "Instructional Technologies and Material Design Course" and "Constructivism and Training Practices Course" each with a participation rate of $11.27 \%$. Besides, $11.27 \%$ of the pre-service science teachers mentioned the "Robotic Coding Education/Course" and $8.45 \%$ of them mentioned the "STEM seminar and distance education" and similar courses and projects as being influential on their acquisition of knowledge about 21 st-century skills.

Mentioning different trainings and courses, mathematics teacher candidates expressed fewer common views. Some $18.64 \%$ of the pre-service math teachers mentioned "the projects attended", $11.86 \%$ of them mentioned "Instructional Technologies and Material Design Course", another 11.86\% specified "Technological Programs and Their Application", and 10.17\% mentioned "Robotic Coding Education/Course" and "Geometry Education and Related Computer Courses" and similar courses and trainings as having contributed to their learning and application of 21 st-century skills. The resources and trainings listed by pre-service mathematics teachers appear to be mostly computer and technology supported lessons and courses. 


\section{Discussion}

The results obtained from the research are presented by discussing them within the framework of the research problems.

In order to help students to develop twenty-first century learning skills, teachers as key agents of education need to have reasonable perceptions of these skills (Sang et al., 2018). It was observed in the present study that teacher candidates, who are the teachers of the future, generally meet this expectation. Based on the concepts that pre-service science and mathematics teachers have about 21 st-century skills, the main categories of a list of skills expected from individuals in the 21st-century such as "Learning and Innovation Skills", "Life and Career Skills" and "Technological Skills" have been created. Again, 21st-century skills woven with contemporary concepts relating to subcategories like "cognitive skills", "process skills", "communication and collaboration skills", "initiative and self-direction skills", "career skills", and "technology knowledge/usage/production skills" indicate that teacher candidates are knowledgeable about 21 st-century skills. With the most common view, teacher candidates stated concepts related to $4 \mathrm{C}$ skills (creativity, critical thinking, collaboration and communication skills) and innovation skills, which belong to the category of "learning and innovation skills", among 21st-century skills (Kozikoğlu \& Altunova, 2018; Almerich et. al., 2018; Bedir, 2019). "Entrepreneurial skills" in the life and career skills category and "technology usage skill" and "software-coding skill" in the category of technological skills were at the top of the skills mentioned by the majority of pre-service teachers.

It was also find out that, at a conceptual level, pre-service science and mathematics teachers mastered many of the skills included in 21st-century framework lists (P21,2019; OECD, 2018; NRC, 2012; ATC21S, 2010; EnGauge, 2002) and national curricula (MEB, 2018a, 2018b; AASL, 2009; NSB, 2010), such as creativity, innovation skills, scientific process skills, design skill, communication skill, collaboration, entrepreneurship, social and intercultural skills, ethical skills, engineering design, technological skills, etc. It has been revealed in this context that pre-service teachers are aware of what the 21 st-century learner skills should be (Günüç, Odabaş1, \& Kuzu, 2013; Fisser \& Thijs, 2015; Almerich et al., 2018; Bedir, 2019; Shidiq \& Yamtinah, 2019).

When giving examples of 21 st-century skills, pre-service science and mathematics teachers included numerous skills, but in their evaluations of their self-skills as regards which of these skills they think they have, they mentioned fewer 21 st-century skill concepts. It can be said, in this sense, that the self-skill competency perceptions of pre-service science $(68.10 \%)$ and math teachers $(65.96 \%)$ are close to each other and at a medium level. In addition, it was shown that pre-service science teachers considered themselves more competent in cognitive skills (creative thinking, innovative thinking, etc.), process skills (scientific process skills, psychomotor skills, laboratory skills, design skills), and collaboration and communication skills, but that their technological skill competencies were lower (Valtonen et al., 2017). The self-competency perceptions of pre-service mathematics teachers regarding imagination and communication skills, which are included in the category learning and innovation skills, and especially technology usage and software-coding skills were higher (Kozikoğlu \& Altunova, 
2018).

When 21st-century skills are examined, it is seen that some of them are skills that are used effectively in all areas, but some are specific to specific fields/disciplines (Çepni \& Ormanc1, 2018). In this sense, differences of opinion regarding 21 st-century skill categories were also identified among pre-service science and mathematics teachers from different branches (Tican \& Deniz, 2019). Pre-service science teachers have both more code diversity and high frequency participation in cognitive skills (creative, innovative, analytical thinking), process skills (scientific process skills, psychomotor skills, laboratory skills, etc.) and career-related skills (engineering design, scientific literacy). Pre-service mathematics teachers, on the other hand, expressed more common views on collaboration and communication skills, initiative and self-direction skills, attitude and value skills, and technology knowledge/usage/ production skills, and they provided a higher rate of skill examples in initiative/self-direction and technological skills than pre-service science teachers. Similarly, it is stated in the literature that the skills that prospective teachers mostly state and apply are innovation, creativity, research, collaboration, problem solving, critical thinking, technology skills, social skills, cognitive skills and communication skills (Günüç, Odabaşı, \& Kuzu, 2013; Göksün \& Kurt, 2017). Consistent with the results of pre-service mathematics teachers, Bedir (2019) emphasized that pre-service teachers perceive " 21 st-century learning" as a process of integration of technology into classroom teaching. As a matter of fact, the perceptions of the mathematics teachers regarding 21 st-century skills and self-skills, which were found to be high in the study, were mostly on technology-oriented skills. Additionally, while science teacher candidates stated a high variety and more common concepts related to 21 st-century skills, mathematics teacher candidates had a lower number of skill views with high-frequency. It is considered that this is due to the structures of their curricula and course contents related to science and mathematics education (Göksün \& Kurt, 2017). Arguing that teachers in different branches conceptualize and perceive curricular gains in a very comprehensive and distinctive way, Van de Oudeweetering and Voogt (2018) also refer to interpretation processes that vary according to individuals and the education received as regards the definitions and skill classifications of 21 st-century skills. Based on the differences in the 21 st-century skill concepts of science and mathematics teacher candidates and the skills they focused on in connection with their branches, it was found out that this situation was mostly due to the courses they took in undergraduate education. The concepts presented by teacher candidates are generally similar to the concepts related to the outcomes of the course contents they received in undergraduate education.

This result was further supported by the fact that undergraduate courses comprised most of the examples given by the pre-service science teachers in terms of their statements about their history of courses, lessons and projects that enabled them to learn 21st-century skills. Rotherham and Willinham (2009) emphasized that different variables such as school structure, curriculum and the teacher effect may be involved in the acquisition of 21 st-century skills. The most emphasized courses include nature of science, special teaching methods, instructional technologies-material design, constructivist approach, science teaching practices and curriculum development. The 21 st-century skills stated by pre-service science teachers, 
such as creative thinking, analytical thinking skills, scientific process skills, multiple intelligence skills (psychomotor skills, visual skills, logical skills, etc.), communication and collaboration skills, engineering design skills, innovation, entrepreneurship and life skills, are found in the "secondary school science curriculum" (MEB, 2018a) that they will teach in the future and, therefore, also included in their undergraduate course contents (YÖK, 2019a). MEB (2018a) takes constructivist learning philosophy as a basis. Thus, students are trained for scientific literacy skills with scientific process skills through science classes. Based on these two skills, it is hoped that science students will develop the 21 st-century skills they need (Turiman, et al., 2012). The existence of a positive correlation between teachers' perceptions of 21st-century skills and their perceptions of constructivist learning environment (Karademir, Sarıahya, \& Altunsoy, 2017) shows itself in the foundation of the 21st-century skill perceptions of pre-service teachers trained for constructivist learning environments. It is thought that the continuous revision of secondary school curricula and the frequent discussion of new gains in undergraduate courses enable pre-service teachers to master 21 st-century skills and the process of gaining these skills.

An examination of the common aspects of the resources and trainings mentioned by pre-service mathematics teachers for 21 st-century skills shows that they mostly gave examples of computer and technology supported courses contained in their undergraduate curriculum (YÖK, 2019b). Similarly, creativity, imagination, problem solving, communication, intelligence games, entrepreneurship and technology skills, which are underlined in "secondary school math curriculum" (MEB, 2018b) that included in their undergraduate courses, are the 21 st-century skills specified by the majority of pre-service mathematics teachers. It was determined that, in terms of skills belonging to the category of technology knowledge/usage/production, pre-service mathematics teachers expressed common views at a higher frequency than pre-service science teachers because they take a higher number of computer and technology supported courses. Considering the results obtained, in order to train teachers and teacher candidates with all these skills, the importance of designing teacher education models or curricula so as to meet the 21 st-century requirements is obvious (Ananiadou \& Claro, 2009; Tutkun \& Aksoyalp, 2010). As for out-of-school trainings that enabled them to learn 21 st-century skills, pre-service science and mathematics teachers mostly gave examples like "Robotics-Coding Education/Course", "Project Participation" and "STEM Seminar and Distance Education of STEM". Pre-service mathematics teachers mentioned their participation in projects more than other trainings. It can be considered that this increased their knowledge of technology. Wan Husin et al. (2016) point out that formal education that might be provided in out-of-school learning environments can improve students' interest in STEM and their 21 st-century skill levels. Trainings other than undergraduate education also increased pre-service teachers' awareness of modern approaches, but apart from a few contemporary concepts such as robotics-coding and STEM, this did not differentiate them from other pre-service teachers. This might be due to the fact that the courses and trainings provided outside of school are shorter than the education that pre-service teachers receive during their undergraduate degree.

The present study found out that the greatest effects on the 21 st-century skills of pre-service 
science and mathematics teachers are the curricula and the education they are taught. Besides, the emphases of teaching and gains that differentiate between these trainings and curricula causes pre-service teachers to learn different concepts on a branch basis. In this context, there is a need for more systematic education curricula, curricular gains and activities in which 21 st-century skills are included more clearly in order for 21 st-century skills to be comprehensible, to be applied more systematically in the education process and to support professional development activities (Farisi, 2016; Karademir, Sarıkahya \& Altunsoy, 2017, van de Oudeweetering \& Voogt 2018; Bedir, 2019). In addition, based on these results, the following can be suggested:

$\checkmark$ Other reasons underlying the differences regarding the skill concepts on branch basis can be revealed by working with pre-service teachers from different fields. In this context, it can be ensured that candidates are given effective feedback and those curricula which, according to the results of the present research, are effective in gaining 21 st-century skills are revised.

The effects of curricula on 21 st-century skills in terms of knowledge and application should be investigated at different levels of the education system with the involvement of academicians, pre-service teachers, teachers, and students.

$\checkmark$ Experimental studies can be conducted on pre-service teachers, some of whose perceptions about skill concepts and 21 st-century self-skills were determined in the present study by analyzing their views, in order to reveal their levels of 21 st-century self-skills and the consistency of this with their views.

\section{Acknowledgements}

We extend our thanks to the pre-service science and mathematics teachers who participated in this study.

\section{Disclaimer}

Part of this research is presented at the $\mathrm{VI}^{\text {th }}$ International Eurasian Educational Research Congress.

\section{References}

AASL. (2009). Standards for the 21st-Century Learner in Action (E-book ed.). United States of America: American Association of School Librarians.

Akgündüz, D., Aydeniz, M., Çakmakçı, G., Çavaş, B., Çorlu, M., Öner, T., \& Özdemir, S. (2015). STEM eğitimi Türkiye raporu: “Günümüz modası mı yoksa gereksinim mi? ” İstanbul: İstanbul Aydın University STEM Centre.

Almerich, G., Díaz-García, I., Cebrián-Cifuentes, S., \& Suárez-Rodríguez, J. (2018). Dimensional structure of 21 st century competences in university students of education. E-Journal of Educational Research, Assessment and Evaluation, 24, 1-20. http://doi.org/ 10.7203/relieve.24.1.12548

Ananiadou, K., \& Claro, M. (2009). 21st century skills and competences for new millennium 
learners in OECD countries. Paris: Organization for Economic Cooperation and Development. Retrieved from http://www.oecd-ilibrary.org/education/21st-century-skillsand-competences-for-new-millennium-learners-in-oecd-countries_218525261154

Aslan, S. (2015). Is learning by teaching effective in gaining 21 st century skills? The views of pre-service science teachers. Educational Sciences: Theory \& Practice, 15(6), 1441-1457. https://doi.org/10.12738/estp.2016.1.0019

Astuti, A. P., Aziz, A., Sumarti, S. S., \& Bharati, D. A. L. (2019). Preparing 21st century teachers: implementation of $4 \mathrm{C}$ character's pre-service teacher through teaching practice. Journal of Physics: Conference Series, 1233(1), 012109. https://doi.org/10.1088/1742-6596/ $1233 / 1 / 012109$

Bedir, H. (2019) Pre-service ELT teachers' beliefs and perceptions on the 21st century learning and innovation skills (4Cs). Journal of Language and Linguistic Studies, 15(1), 231-246. https://doi.org/10.17263/j1ls.547718

Bell, S. (2010). Project-based learning fo the 21st century: Skills for the future. The Clearing House, 83, 39-43. https://doi.org/10.1080/00098650903505415

Bialik, M., \& Fadel, C. (2015). Skills for the 21st century: What should students learn. Centre for Curriculum Redesign, Boston, Massachusetts. Retrieved April 17, 2019, from file://C:/Users/USER/Downloads/CCR-Skills_FINAL_June2015.pdf

Binkley, M., Erstad, O., Herman, J., Raizen, S., Ripley, M., \& Rumble, M. (2010). Draft White Paper 1: Defining 21st century skills, ATCS (Assesment \& Teaching of 21st Century Skills) Framework for 21st Century Learning. The University of Melbourne, Australia. https://doi.org/10.1007/978-94-007-2324-5_2

Bozkurt Altan, E. (2017). Fen, teknoloji, mühendislik ve matematik (FeTeMM-STEM) eğitimi. In H. G. Hastürk (Ed.), Teoriden pratiğe fen bilimleri öğretimi (pp. 354-388). Ankara: Pegem Academy. https://doi.org/10.14527/9786053189879.11

Chalkiadaki, A. (2018). A Systematic Literature Review of 21st Century Skills and Competencies in Primary Education. Internasional Journal of Instructions, 11(3). https://doi.org/10.12973/iji.2018.1131a

Çepni, S., \& Ormanc1, Ü. (2018). Geleceğin dünyası. In S. Çepni (Ed.), Kuramdan uygulamaya STEM+A+E eğitimi. Ankara: Pegem Publishing. https://doi.org/10.14527/97860 52410561

Farisi, M. I. (2016). Developing the 21st-century social studies skills through technology integration. Turkish Online Journal of Distance Education, 17(1), 16-30. https://doi.org/ 10.17718/tojde.47374

Fisser, P., \& Thijs, A. (2015). Integration of 21st century skills into the curriculum of primary and secondary education. Paper presented at the Society for Information Technology \& Teacher Education International Conference. Las Vegas, NV, United States. 


\section{Mll Macrothink}

Gardner, H., \& Hatch, T. (1989). Educational Implications of The Theory of Multiple Intelligences. Educational Researcher, 18(8), 4-10. https://doi.org/10.3102/0013189X018 008004

Göksün, D. O., \& Kurt, A. A. (2017). Öğretmen adaylarının 21. yüzyı1 öğrenen becerileri kullanımları ve 21. yüzyıl öğreten becerileri kullanımları arasındaki ilişki. Education and Science, 42(190), 107-130. https://doi.org/10.15390/EB.2017.7089

Günüç, S., Odabaşı, F., \& Kuzu, A. (2013). The defining characteristics of students of the 21st century by student teachers: A twitter activity. Journal of Theory and Practice In Education, 9(4), 436-455.

Hacıŏlu, F. (1990). 21. Yüzy1l İçin Öğretmen Eğitimi. Education and Science, 14(77), 48-53.

Jacobson-Lundeberg, V. (2016). Pedagogical Implementation of 21st Century Skills. Educational Leadership and Administration: Teaching and Program Development, 27, 82-100.

Korkmaz, Ö. (2009). Öğretmenlerin eleştirel düşünme eğilim ve düzeyleri. Ahi Evran University, Journal of Kırşehir Education Faculty, 10(1), 1-13.

Kozikoğlu, İ., \& Altunova, N. (2018). Öğretmen Adaylarının 21. Yüzyıl Becerilerine İlişkin Öz-yeterlik Algılarının Yaşam Boyu Öğrenme Eğilimlerini Yordama Gücü. Journal of Higher Education and Science, 8(3), 522-531. https://doi.org/10.5961/jhes.2018.293

Lemke, C. (2002). en Gauge 21st century skills: Digital literacies for a digital age. Naperville, IL: North Central Regional Educational Lab. Retrieved from https://eric.ed.gov/?id= ED463753

Lyons, D., \& Wells, M. (2015). 21st Century Literacy-Perceptions of and Influences on Year 6 Teachers in Victorian Classrooms. Australian Association for Research in Education, (pp. 1-12). AARE Conference, Western Australia.

MEB (Milli Eğitim Bakanlığı). (2017). STEM eğitimi ögrretmen el kitabı. Turkish Ministry of National Education: General Directorate of Innovation and Educational Technologies. Retrieved from http://fclturkiye.eba.gov.tr/wp-content/uploads/2021/01/stem-eğitimi-öğretm en-el-kitabi.pdf

MEB (Milli Eğitim Bakanlığı). (2018a). Fen bilimleri dersi öğretim programı (İlkokul ve Ortaokul 3, 4, 5, 6, 7 ve 8. Siniflar). Ankara: Ministry of National Education.

MEB (Milli Eğitim Bakanlığı). (2018b). Matematik dersi öğretim programı (İlkokul ve Ortaokul 3, 4, 5, 6, 7 ve 8. Siniflar). Ankara: Ministry of National Education.

Mihladız, G. (2017). Fen öğretiminde çoklu zeka. In H. G. Hastürk (Ed.), Teoriden pratiğe fen bilimleri ögretimi (pp. 141-186). Ankara: Pegem Academy. https://doi.org/10.14527/97860 53189879.05

Mullis, I. V. S. (2019). TIMSS 2019: Monitoring Trends in Mathematics and Science 
Achievement Martin. In M. O. E. Martin \& I. V. S. Mullis (Eds.), TIMSS 2019 Assessment Frameworks (pp. 3-10). TIMSS \& PIRLS International Study Center, Lynch School of Education, Boston College.

National Academy of Sciences. (2007). Rising above the gathering storm: Energizing and employing America for a brighter economic future. Washington, DC: The National Academies Press.

NRC (National Research Council). (2012). Education for Life and Work: Developing Transferable Knowledge and Skills in the 21st Century. Washington, DC: The National Academies Press. https://doi.org/10.17226/13398

NSB (National Science Board). (2010). Preparing the next generation of STEM innovators: Identifying and developing our nations' human capital. Retrieved from http://www.nsf.gov/ nsb/publications/2010/nsb1033.pdf

OECD (Organization for Economic Cooperation and Development). (2018). The future of education and skills Education 2030. Retrieved from http://www.oecd.org/education/2030

OECD (Organization for Economic Cooperation and Development). (2017). "Data sources", in OECD Science, Technology and Industry Scoreboard 2017: The Digital Transformation. OECD Publishing, Paris. https://doi.org/10.1787/9789264268821-en

P21 (The Partnership for 21st Century Skills). (2019). Framework for 21st Century Learning Definitions. Retrieved from http://www.battelleforkids.org/networks/p21/frameworks-resources

Padilla-Diaz, M. (2015). Phenomenology in educational qualitative research: Philosophy as science or philosophical science? International Journal of Educational Excellence, 1(2), 101-110. https://doi.org/10.18562/IJEE.2015.0009

Rotherham, A. J., \& Willingham, D. (2009). To work, the 21 st century skills movement will require keen attention to curriculum, teacher quality, and assessment. Educational Leadership (p. 9).

Saldana, J. (2019). Nitel Araştırmacılar Iç̧in Kodlama El Kitabı. Ankara: Pegem Academy.

Sang, G., Liang, J., Chai, C., Dong, S., \& Tsai, Y. (2018). Teachers' actual and preferred perceptions of twenty-first century learning competencies: A chinese perspective. Asia Pacific Education Review, 19(3), 307-317. https://doi.org/10.1007/s12564-018-9522-0

Shidiq, A. S., \& Yamtinah, S. (2019). Pre-service chemistry teachers' attitudes and attributes toward the twenty-first century skills. Journal of Physics: Conference Series, 1157(4). https://doi.org/10.1088/1742-6596/1157/4/042014

Siddiq, F., Scherer, R., \& Tondeur, J. (2016). Teachers' emphasis on developing students' digital information and communication skills (TEDDICS): A new construct in 21st century education. Computers \& Education, 92-93, 1-14. https://doi.org/10.1016/j.compedu.2015. 10.006

Silva, E. (2008). Measuring skills for the 21st century. Washington, DC: Education Board. 
Trinidad, G., Patel, D., Shear, L., Goh, P., Quek, Y. K., \& Tan, C. K. (2013). Teaching 21st century competencies: Lessons from Crescent girls'school in Singapore. Paper presented at the International Conference on Educational Technologies (ICEduTech). Retrieved from https://www.learntechlib.org/p/158209

Turiman, P., Omar, J., Daud, A. M., \& Osman, K. (2012). Fostering the 21st Century Skills through Scientific Literacy and Science Process Skills. Procedia-Social and Behavioral Sciences, 59(0), 110-116, 2012. https://doi.org/10.1016/j.sbspro.2012.09.253

Tutkun, O. F., \& Aksoyalp, Y. (2010). 21 yüzyılda öğretmen yetiştirme eğitimi programının boyutlar1. Journal of the Institute of Social Sciences of Selçuk University, 24, 361-370.

TYC (Türkiye Yeterlilikler Çerçevesi). (2015). Türkiye yeterlilikler çerçevesi. Turkey Vocational Qualifications Authority, Official Newspaper Date: 02/01/2016, Ankara.

Urbani, J. M., Roshandel, S., Michaels, R., \& Truesdell, E. (2017). Developing and modeling 21 st-century skills with preservice teachers. Teacher Education Quarterly, 44(4), 27-50.

Valtonen, T., Sointu, E. T., Kukkonen, J., Häkkinen, P., Järvelä, S., Ahonen, A., ... Mäkitalo-Siegl, K. (2017). Insights into Finnish first-year pre-service teachers' perceptions of their 21st century skills. Education and Information Technologies, 22(5), 2055-2069. https://doi.org/10.1007/s10639-016-9529-2

Van de Oudeweetering, K., \& Voogt, J. (2018). Teachers' conceptualization and enactment of twenty-first century competences: Exploring dimensions for new curricula. The Curriculum Journal, 29(1), 116-133. https://doi.org/10.1080/09585176.2017.1369136

Wan Husin, W. W., Mohamad Arsad, N., Othman, O., Halim, L., Rasul, M. S., Osman, K., \& Iksan, Z. (2016). Fostering students' 21st century skills through project oriented problem based learning (POPBL) in integrated STEM education program. Asia-Pacific Forum on Science Learning \& Teaching, 17(1), 60-77.

YOK (Yüksek Öğretim Kurumu). (2019a). Fen bilgisi öğretmenliği lisans programı. Retrieved from https://www.yok.gov.tr/documents/kurumsal/egitim_ogretim_dairesi/ogretm en-yetistirme/fen_bilgisi.pdf

YOK (Yüksek Öğretim Kurumu). (2019b). İlköğretim matematik öğretmenliği lisans programı. Retrieved from https://www.yok.gov.tr/documents/kurumsal/egitim_ogretim_daire si/ogretmen-yetistirme/ilkogretim_matematik.pdf

\section{Copyright Disclaimer}

Copyright for this article is retained by the author(s), with first publication rights granted to the journal.

This is an open-access article distributed under the terms and conditions of the Creative Commons Attribution license (http://creativecommons.org/licenses/by/3.0/). 